\title{
Mucus-net feeding by the vermetid gastropod Dendropoma maxima in coral reefs
}

\author{
Isabella Kappner ${ }^{1, *}$, Salim M. Al-Moghrabi ${ }^{2}$, Claudio Richter ${ }^{1}$ \\ ${ }^{1}$ Zentrum für Marine Tropenökologie, Fahrenheitstr. 1, 28359 Bremen, Germany \\ ${ }^{2}$ University of Jordan, Marine Science Station, PO Box 195, Aqaba, Jordan
}

\begin{abstract}
Dendropoma maxima (Vermetidae, Mollusca) is the largest member of a conspicuous group of sessile gastropods living in shallow tropical and temperate reefs. In the northern tip of the Gulf of Aqaba, Red Sea, individuals of $D$. maxima live in tubes embedded in the carbonate framework of the reef flat at densities of $11.1 \pm 6.3 \mathrm{~m}^{-2}$. They secrete mucus nets extending $\sim 10 \mathrm{~cm}$ around the individuals. The sticky nets billow under the turbulent action of impinging waves and indiscriminately trap suspended particles. The nets are withdrawn at regular intervals and consumed. Net retraction frequency (NRF), as determined by time-lapse video in the laboratory and in the field, appears to be related to particle availability with significant differences between day $\left(1.35 \pm 0.16\right.$ hauls $\left.h^{-1}\right)$ and night $\left(2.39 \pm 0.44\right.$ hauls $\left.h^{-1}\right)$, corresponding to differences in the availability of phyto- and zooplankton. With each net load, the snail consumes $10.43 \pm$ $0.99 \mu \mathrm{g}$ chlorophyll $a$. Zooplankton accounts for about the same amount of ingested food as phytoplankton, the bulk of which is ingested during the night. Community ingestion amounts to $0.9 \pm 0.5 \mathrm{~g} \mathrm{C} \mathrm{m}^{-2} \mathrm{~d}^{-1}$, showing that mucus-net feeding by $D$. maxima traps plankton at rates comparable to other sessile suspension feeders in the same coral reefs.
\end{abstract}

KEY WORDS: Feeding $\cdot$ Mucus net $\cdot$ Carbon uptake $\cdot$ Pelagicbenthic coupling - Coral reef · Vermetidae · Dendropoma maxima

Resale or republication not permitted without written consent of the publisher

Sessile vermetids are a rather peculiar family of warm-temperate and tropical snails, which in the course of their evolution have reverted from mobile ancestral forms to a sessile life. Their shell has become untwisted and vermiform, cemented to, or embedded in the substratum, usually in zones of high wave action. In high densities, their bulky shells can contribute sig-

*Present address: Department of Zoology, Division of Invertebrates, Field Museum of Natural History, 1400 S. Lake Shore Drive, Chicago, Illinois 60605-2496, USA.

E-mail: ikappner@fmnh.org nificantly to reef rock accretion on the outer reef-flat (Safriel 1966, 1975, Shier 1969).

Juvenile vermetids are mobile and carry coiled shells (Thiele 1963, Keen 1971). After settling, the shell becomes attached to the reef and elongates without further coiling. The resulting linear growth of the shell is rather fast and enables the vermetid to escape overgrowth by corals and to maintain access to food (Smalley 1984).

Vermetids have evolved a distinctive feeding strategy: the scavenging of food particles by a mucus net. While the general feeding behaviour and diet of Dendropoma maxima has been the subject of earlier investigations (Hadfield 1970, Hadfield et al. 1972, Hughes \& Lewis 1974), a quantitative assessment of mucus-net feeding is still wanting.

In the present paper, we used novel video-techniques, in situ and in the laboratory, to describe the relationship between the feeding behaviour of Dendropoma maxima and environmental factors in the northern Gulf of Aqaba, Red Sea. Our study provides, for the first time, quantitative information about the food content trapped in the sticky nets as well as an estimate of the carbon uptake by sessile mucus-net feeders at the reef crest.

Methods. Field work was carried out in the northern tip of the Gulf of Aqaba (Red Sea) along the Jordanian and Israeli coastlines, during the period from May 15 to September 15, 1997. The analyses of samples and evaluation of data collected were performed in the laboratories of the Marine Science Station (MSS), Aqaba, and the Center of Tropical Marine Ecology (ZMT), Bremen. The abundance of Dendropoma maxima was determined at 6 different sites along the Jordanian side and at 2 along the Israeli coastline. Thirty quadrats, $1 \mathrm{~m}^{2}$ each, were placed randomly within a total area of $200 \mathrm{~m}^{2}$ on the reef flat at $\sim 0.5 \mathrm{~m}$ depth in order to 
obtain density counts and opercula-size frequencies (Kappner et al. unpubl.).

Feeding activity field and laboratory experiments: Net retraction frequency (NRF) characterised the feeding activity of the snails as net hauls $\mathrm{h}^{-1}$, while net retraction time (NRT) was defined as the period between the initiation of net-retraction and the completion of net ingestion. NRF and NRT were determined by time-lapse video recordings in the field and in the laboratory. To this effect, a digital videocamera (Sony DCR-VX1000E) in an underwater housing (Amphibico VH 1000) was positioned on a tripod on the reef-flat, zooming in a detail-frame of $25 \times 25 \mathrm{~cm}$ so that 2 individual snails could be observed on the screen. Night-time observations were made under indirect light using a dim $10 \mathrm{~W}$ lamp placed $0.5 \mathrm{~m}$ away from the snails. Multiple battery packs enabled us to record for $2 \mathrm{~s}$ duration every $30 \mathrm{~s}$ for periods of $6 \mathrm{~h}$. At least $8 \mathrm{~h}$ were needed for recharging the batteries between the $6 \mathrm{~h}$ recordings; therefore it took a total of 14 filming days to obtain triplicate records of every $6 \mathrm{~h}$ day or night interval.

In contrast to Yonge (1932) we managed to keep 4 Dendropoma maxima active for the 2 mo duration of our study by using a flow-through system at the MSS laboratory. Within the $100 \mathrm{l}$ aquarium, a circulationpump turned over the water at $8.31 \mathrm{~min}^{-1}$. A ventilation-air-stone provided aeration. Furthermore, the small air bubbles attached to the translucent mucus strands rendered the nets visible. Artemia salina and standard aquarium fish-food (JBL Novo BEL) were fed to the snails twice daily $\left(0.25\right.$ to $\left.0.5 \mathrm{~g} \mathrm{ind}^{-1} \mathrm{~d}^{-1}\right)$, around noon and at 20:00 h. Food was consumed or washed out of the flow-through aquarium within less than $1 \mathrm{~h}$.

The feeding activity of the snails was recorded using a time-lapse video over a $9 \mathrm{~d}$ period at the same record/pause intervals as in the field. The diel cycle of light was controlled by a timer set to ambient day length, with a similar set-up as in the field with low levels of indirect light to enable filming at night.

Field sampling of mucus-nets and water-samples: Twice daily, during light and dark hours (12:00 and 20:00 h), for $6 \mathrm{~d}$, water and mucus-net samples were collected over the reef-flat southwest of the MSS. On each occasion 6 water samples (Nalgene bottles), 11 each, were taken from the vicinity of the individuals, at a maximum of $0.5 \mathrm{~m}$ off the bottom. At the same time, we collected 16 individual mucus nets, twisting them around glass-pipettes and storing them in $10 \mathrm{ml}$ glass vials.

The laboratory water and mucus-net samples (5 replicates each) were analysed for chlorophyll $a(\mathrm{chl} a)$ according to the method described in Strickland \& Parsons (1972). The samples were filtered through GF/F filters (Whatman, $25 \mathrm{~mm} \varnothing ; 0.7 \mu \mathrm{m}$ pore-size); pig- ments were extracted in $10 \mathrm{ml} 90 \%$ acetone for $24 \mathrm{~h}$ at $4{ }^{\circ} \mathrm{C}$ and measured by a Turner TD 700 fluorometer. We found no autofluorescence of nets which were collected from snails kept in GF/F-filtered seawater in the laboratory.

The organic carbon of the trapped food was determined by subtracting the carbon content of the filled nets collected in the field from 'empty' nets collected from snails kept in filtered seawater. On every sampling occasion, 6 nets were analysed in a Carlo Erba NA2100 Protein Nitrogen Analyser (Ehrenberger 1991, Yamamuro \& Kayanne 1995). The nets were placed on weighed precombusted $\mathrm{GF} / \mathrm{F}$ filters $\left(550^{\circ} \mathrm{C}, 6 \mathrm{~h}\right)$, rinsed with de-ionised water, dried at $60^{\circ} \mathrm{C}$ for approximately $24 \mathrm{~h}$ and weighed (Mettler Toledo AT21 balance; accuracy of $1 \mu \mathrm{g}$ ). The samples were then mortared, weighed and combusted in tin capsules (NA2000, Fisons Instruments).

Clotted nets rendered microscopic examination of the food items very difficult. Despite much effort, chemical and enzymatic digestion of the net proved unsuccessful. Only the larger and hard-shelled items (crustaceans, nematodes, diatoms, etc.) could be separated from the net and partly enumerated.

Statistical analyses: Statistical analyses were done with Statistika 5.1 (StatSoft Inc.) and Statview. Cochran tests were used to test for homogeneity of variances before ANOVA. Tukey's pairwise comparison technique was used in combination with ANOVA for post hoc comparison of means.

Results. General observations: Dendropoma maxima continuously secretes mucus threads by the combined action of the modified pedal gland and the pedal tentacles. The threads are spread over the substratum under the turbulent action of currents and waves. As the threads are rather tear-resistant and sticky, they interweave in the process forming a rugged sticky net. The net is withdrawn and consumed at intervals, during which the production of mucus threads continues. The very long and elastic oesophagus allows the snail to ingest the net at a higher speed than its subsequent processing in the stomach. Depending on the particle load of the net, the snail swallows it in one or more steps. If overcharged with particles, the net may be cut off altogether by the snail. Turbulent wave action stimulates higher snail activity and mucus production. $D$. maxima is active $24 \mathrm{~h} \mathrm{~d}^{-1}$. However, its general activity decreases during morning hours, during which the snail occasionally withdraws into its tube for a duration of 1 to $15 \mathrm{~min}$ and the production of mucus ceases.

In situ time lapse video: NRF in the field was $1.92 \pm$ $0.32 \mathrm{~h}^{-1}$, but showed significant diel and tidal variations (Fig. 1A, Table 1): during the night, NRF was $77 \%$ higher than during the day, values during flood were $29 \%$ higher than during ebb tide. 
Table 1. Dendropoma maxima. Total mean value, diel and tidal mean values $( \pm \mathrm{SE})$ of net retraction frequency (NRF), net expo-

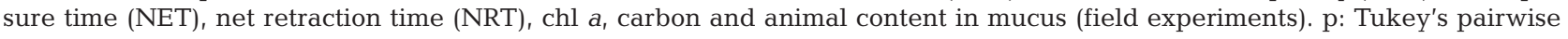
post hoc test; $\mathrm{n}$ : number of samples

\begin{tabular}{|c|c|c|c|c|c|c|c|c|}
\hline & $\mathrm{n}$ & $\begin{array}{c}\text { Total } \\
(\text { mean } \pm \mathrm{SE})\end{array}$ & $\begin{array}{c}\text { Day } \\
(\text { mean } \pm \mathrm{SE})\end{array}$ & $\begin{array}{c}\text { Night } \\
(\text { mean } \pm \text { SE) }\end{array}$ & $\mathrm{p}$ & $\begin{array}{c}\text { Flood } \\
(\text { mean } \pm \mathrm{SE})\end{array}$ & $\begin{array}{c}\text { Ebb } \\
(\text { mean } \pm \mathrm{SE})\end{array}$ & $\mathrm{p}$ \\
\hline NRF (hauls $\mathrm{h}^{-1}$ ) & 134 & $1.92 \pm 0.32$ & $1.35 \pm 0.16$ & $2.39 \pm 0.44$ & $<0.01$ & $2.21 \pm 0.61$ & $1.71 \pm 0.22$ & $<0.01$ \\
\hline NRT (s) & 153 & $171 \pm 11$ & $170 \pm 16$ & $172 \pm 14$ & 0.11 & $162 \pm 17$ & $179 \pm 14$ & 0.43 \\
\hline NET (min) & 134 & $31 \pm 1$ & $44 \pm 3$ & $25 \pm 1$ & $<0.01$ & $27 \pm 2$ & $35 \pm 2$ & $<0.01$ \\
\hline $\mathrm{Chl} \mathrm{a}\left(\mu \mathrm{g} \mathrm{net}^{-1}\right)$ & 50 & $10.43 \pm 0.99$ & $10.67 \pm 1.21$ & $10.16 \pm 1.46$ & 0.79 & $10.15 \pm 1.07$ & $10.50 \pm 1.16$ & 0.88 \\
\hline Trapped Carbon (mg C net ${ }^{-1}$ ) & 87 & $1.93 \pm 0.09$ & $1.83 \pm 0.11$ & $2.06 \pm 0.19$ & 0.31 & $2.12 \pm 0.25$ & $1.86 \pm 0.11$ & 0.28 \\
\hline Zooplankton (ind. net ${ }^{-1}$ ) & 48 & $1.63 \pm 0.53$ & $0.38 \pm 0.12$ & $2.88 \pm 0.57$ & $<0.01$ & $0.74 \pm 0.29$ & $2.21 \pm 0.73$ & 0.09 \\
\hline Meiofauna (ind. net ${ }^{-1}$ ) & 48 & $2.92 \pm 0.48$ & $2.58 \pm 0.73$ & $3.25 \pm 0.64$ & 0.07 & $3.26 \pm 1.01$ & $2.69 \pm 0.54$ & 0.51 \\
\hline Foraminifera (ind. net ${ }^{-1}$ ) & 48 & $2.27 \pm 0.45$ & $2.63 \pm 0.75$ & $1.92 \pm 0.48$ & 0.15 & $2.84 \pm 0.86$ & $1.90 \pm 0.51$ & 0.14 \\
\hline
\end{tabular}

NRT amounted to $\sim 3$ min (Table 1). In contrast to $\mathrm{NRF}$, we found no diel or tidal differences for NRT; however, nets which were exposed for a longer period

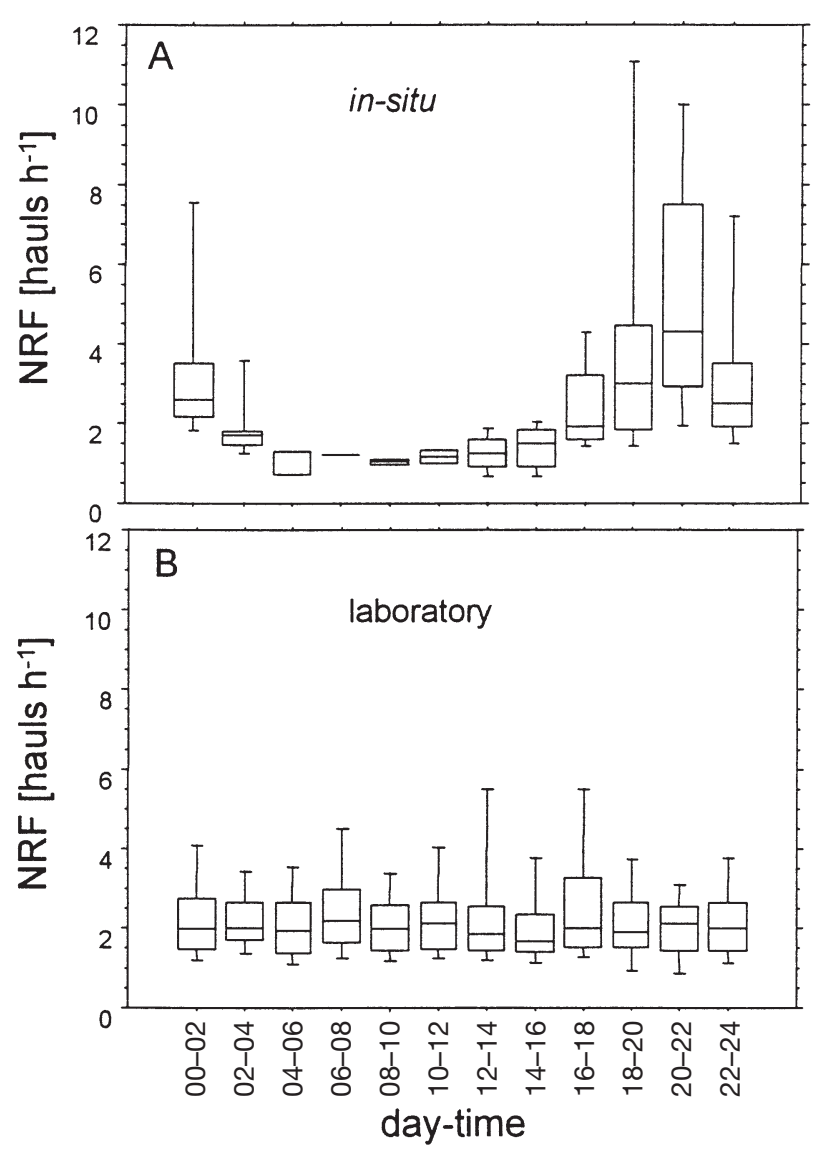

Fig. 1. Dendropoma maxima. Feeding activity, with boxwhisker plots (median, box: 25 and $75 \%$, whiskers: minimal and maximal of values) denoting number of net-hauls $\mathrm{h}^{-1}$ during $1 \mathrm{~d}$. The abscissa shows 1 whole day separated into $2 \mathrm{~h}$ intervals. (A) In situ observations and (B) laboratory observations using time lapse video of time required longer handling times by the snails (Table 2).

Laboratory observations: NRF in the lab was similar to the frequencies found in the field, amounting to $1.79 \pm 0.10 \mathrm{~h}^{-1}$, equivalent to a net exposure time of $34 \pm 1 \mathrm{~min}$. However, as opposed to our field results, we found no diel changes in NRF.

NRT amounted to $173 \pm 4 \mathrm{~s}$ and was close to NRT in the field. We found no diel changes or any other temporal variability in NRT in the laboratory (Fig. 1B).

Food quantity and quality: Field collected nets were loaded with $1.9 \pm 0.1 \mathrm{mg}$ organic $\mathrm{C}_{\text {net }}{ }^{-1}$. Empty mucus nets from snails reared in $0.7 \mu \mathrm{m}$ filtered seawater contained only $0.16 \mathrm{mg} \mathrm{C}$ net $^{-1}$. Chl $\mathrm{a}$ in the nets amounted to $10.43 \pm 0.99 \mu \mathrm{g} \mathrm{net}^{-1}$. We found no significant diel or tidal differences in the amount of chl $a$ and carbon contents of the food (Table 1), in spite of the observed differences in NRF.

Chl a concentrations in the water near the coral reef were generally low $\left(0.16 \pm 0.01 \mu \mathrm{g} \mathrm{l}^{-1}\right)$, with significant variations between day and night $(0.14 \pm 0.01$ and $0.18 \pm 0.01 \mathrm{~g} \mathrm{l}^{-1}$, respectively, $\left.\mathrm{p}=0.02\right)$, as well as between flood and ebb $(0.21 \pm 0.01$ and $0.15 \pm 0.01 \mu \mathrm{g}$ $\mathrm{l}^{-1}$, respectively, $\left.\mathrm{p}<0.01\right)$.

Microscopic analysis of the nets showed that phytoplankton and zooplankton, as well as benthic diatoms and nematodes, were trapped in the mucus nets

Table 2. Dendropoma maxima. Mean value $( \pm \mathrm{SE})$ of net exposure time to different net retraction times (NRT) arranged in intervals

\begin{tabular}{|lc|}
\hline $\begin{array}{l}\text { NRT interval } \\
(\mathrm{min})\end{array}$ & $\begin{array}{c}\text { Mean }( \pm \mathrm{SE}) \\
\text { net exposure time }(\mathrm{min})\end{array}$ \\
\hline $0-1$ & $24 \pm 2$ \\
$1-2$ & $33 \pm 3$ \\
$2-3$ & $35 \pm 4$ \\
$>3$ & $34 \pm 2$ \\
\hline
\end{tabular}


(Table 1). Other items encountered were filamentous algae, fragments of macroalgae, faeces and detritus.

Nematode meiofauna did not vary significantly between day and night (Table 1). However, significantly more zooplankton was captured during the night than during the day. Copepods dominated the catches (69\% of individuals).

Discussion. As opposed to ascidians or bivalves which continuously produce mucus sheaths within their body cavities in conjunction with an active transport of water (Jørgensen 1966), Dendropoma maxima exposes discrete mucus nets to the ambient water. As in the case of their pelagic relatives, the pteropods (Jackson 1993), the exposed sticky nets act as 'flypaper', sequestering suspended material from the surrounding waters.

The amount of particles trapped by each net is a function of particle concentration and replacement rate, as well as size and exposure time of the net. Organic material increases in parallel with the total amount of particles sequestered, but the ratio of organic:total material sequestered is not constant. Dendropoma maxima ensures a constant ration of organic carbon taken up with each net by adjusting the exposure time of the net to the availability of suspended food: when daytime chl a and zooplankton concentrations are low, nets are exposed longer than during the night when the reef is swamped with demersal zooplankton. The advantage of minimising the variation in ration size is to increase processing efficiency of the net. In fact, nets which have been exposed for a longer period of time seem more difficult to handle, as evidenced in higher retraction times (Table 2): these nets are engulfed step by step. As the load with indigestible particles increases, more time is needed for removing the debris. A similar increase in handling time was observed for the vermetid Tripsycha tulipa (Hughes 1985).

We can only speculate on the cues triggering the retraction of the net. Mussel pulp causes Vermetus gigas to protract from its tube (Boettger 1930), and chemical as well as mechanical cues may be responsible for aggressive behaviour in Tripsycha tulipa, which is reported to snatch mucus nets from the mouths of neighbouring individuals, sometimes inflicting lesions (Hughes 1985). However food loading is an unlikely mechanical or chemical trigger for net retraction in Dendropoma maxima, as the relatively small increase in drag or scent is difficult to perceive against the turbulent background surrounding the snail in situ.

Hunger or saturation level could not act as Zeitgeber as they would tend to counteract the observed NRF by increasing and decreasing NRF, respectively. Also, food saturation does not seem to occur in Dendropoma maxima: in the Red Sea proper, net retrieval may proceed at more than twice the maximum rates (Hughes \& Lewis 1974) observed in the Gulf of Aqaba (this study).

Ingestion amounts to $81 \mathrm{mg} \mathrm{C}$ ind. ${ }^{-1} \mathrm{~d}^{-1}$, were observed, with algae, animals and detritus providing roughly equal shares of the ingested food. This is a daily ration of $41 \%$ of the snail's body weight $\mathrm{d}^{-1}$. This high turnover is surprising for a sessile animal, which usually feature $<3 \%$ of DW d ${ }^{-1}$ (Pütter 1911), but it is in the same range as daily ingestion rates of tropical pelagic pteropods (Gerber 1979). This suggests that the incessant production of nets might be a costly undertaking. Whereas the gains in terms of organic carbon trapped outweigh the investment of net secreted by about 1 order of magnitude, the quality of the net might take its toll: currents and waves exert drag on the net, requiring structural enforcement with tearresistant fibres.

Indeed, empty nets featured low C:N ratios (5.3; Kappner unpubl.) similar to protein-enriched mucus of corals (Pascal \& Vacelet 1981) and were found to be extremely drag-resistant: neighbouring Dendropoma maxima tearing on opposite sides of a common net were found to be able to dislodge a stone weighing $\sim 100 \mathrm{~g}$ under water (Kappner unpubl.). Given the high C:N ratio of the food (15.4; Kappner unpubl.), it appears that Dendropoma maxima trades quantity for quality, spending high quality nets on the collection of low value food. As opposed to suspension feeders on the reef slope and deeper framework which feed rather selectively on various size fractions of the impinging plankton (Hamner et al. 1988, Richter \& Wunsch 1999), D. maxima leads a 'backstage' life in pre-filtered downstream waters. Consequently, it scavenges whatever it can get. Yet, given its affinity to animal food (Boettger 1930), its inherently unselective feeding mode does not preclude a behavioural preference for protein-rich animal prey becoming entangled in the net. In this light, increasing NRF might be seen as an adaptation to minimise escape losses of animal prey entangled in the nets by hauling in the net, as soon as it senses the 'struggling' of the prey. In our aquarium, NRF of neighbouring snails with communal nets was always higher than that of single snails, showing that mechanical cues, e.g. commencement of net retrieval by 1 individual, triggered a similar response in the other. A similar behaviour of synchronised hauling was found in D. corallinaceum (Hughes 1978).

Community ingestion amounts to $0.9 \mathrm{~g} \mathrm{C} \mathrm{m}^{-2} \mathrm{~d}^{-1}$. This value is almost identical to uptake rates by suspension feeders elsewhere in the reef (Fabricius et al. 1998, Yahel et al. 1998, Richter \& Wunsch 1999), showing that pelagic-benthic coupling proceeds at comparable rates in different sections of the reef. 
Acknowledgements. This research was funded by the Red Sea Program for Marine Science, grant no. 03F0151A by the German Federal Ministry of Education and Research (BMBF). The paper constitutes part of I.K.'s MSc thesis, submitted to the University of Bremen, Germany. Special thanks to the staff of the Marine Science Station for assistance in the field, to M. Birkicht and M. Wunsch for technical assistance, and to A. Mazeroll and G. Hempel for reviewing this manuscript.

\section{LITERATURE CITED}

Boettger CR (1930) Studien zur Physiologie der Nahrungsaufnahme festgewachsener Schnecken. Die Ernährung der Wurmschnecke Vermetus. Biol Zentrbl 50:581-598

Ehrenberger F (1991) Quantitative organische Elementaranalyse. Verlagsgesellschaft, Weinheim, p 189-211

Fabricius KE, Yahel G, Genin A (1998) In situ depletion of phytoplankton by an azooxanthellate soft coral. Limnol Oceanogr 43:354-356

Gerber RP (1979) Ingestion of natural particulate organic matter and subsequent assimilation, respiration and growth by tropical lagoon zooplankton. Mar Biol 52:33-43

Hadfield MG (1970) Observations on the anatomy and biology of two California vermetid gastropods. Veliger 12(3): 301-309

Hadfield MG, Kay EA, Gillette MU, Lloyd MC (1972) The vermetidae (Mollusca: Gastropoda) of Hawaiian Island. Mar Biol 12:81-98

Hamner WM, Jones MS, Carleton JH, Hauri IR, Williams DM (1988) Zooplankton, zooplanktivorous fish, and water currents on a windward reef face: Great Barrier Reef, Australia. Bull Mar Sci 42:459-479

Hughes RN (1978) The biology of Dendropoma corallinaceum and Serpulorbis natalensis, two South African vermetid gastropods. Zool J Linn Soc 64:111-127

Hughes RN (1985) Feeding behaviour of the sessile gastropod Tripsycha tulipa (Vermetidae). J Molluscan Stud 51:326-330

Hughes RN, Lewis AH (1974) On the spatial distribution, feeding and reproduction of the vermetid gastropod Dendropoma maximum. J Zool 172:531-547

Editorial responsibility: Otto Kinne (Editor), Oldendorf/Luhe, Germany
Jackson GA (1993) Flux feeding as a mechanism for zooplankton grazing and its implications for vertical particulate flux. Limnol Oceanogr 38(6):1328-1331

Jørgensen CB (1966) Biology of suspension feeding. Pergamon Press, London

Keen AM (1971) Sea shells of tropical West America, 2nd edn Stanford University Press, Stanford, CA, p 400-408

Pascal H, Vacelet E (1981) Bacterial utilisation of mucus on the coral reef of Aqaba (Red Sea). Proc 4th Int Coral Reef Symp Manila 1:669-677

Pütter A (1911) Vergleichende Physiologie. Gustav-FischerVerlag, Jena

Richter C, Wunsch M (1999) Cavity-dwelling suspension feeders in coral reefs - a new link in reef trophodynamics. Mar Ecol Prog Ser 188:105-116

Safriel UN (1966) Recent vermetid formation on the Mediterranean shore of Israel. Proc Malacol Soc Lond 37:27-34

Safriel UN (1975) The role of vermetid gastropods in the formation of Mediterranean and Atlantic reefs. Oecologia 20: 85-101

Shier DE (1969) Vermetid reefs and coastal development in the Ten Thousand Island, Southwest Florida. Geol Soc Am Bull 80:485-508

Smalley TL (1984) Possible effects of intraspecific competition on the population structure of a solitary vermetid mollusc. Mar Ecol Prog Ser 14:139-144

Strickland JDH, Parsons TR (1972) A practical handbook of seawater analysis. Bull Fish Res Board Can 167

Thiele J (1963) Handbuch der systematischen Weichtierkunde. Gustav-Fischer-Verlag, Jena, p 185-187

Yahel G, Post AF, Fabricius KE, Marie D, Vaulot D, Genin A (1998) Phytoplankton distribution and grazing near coral reefs. Limnol Oceanogr 43:551-563

Yamamuro M, Kayanne H (1995) Rapid direct determination of organic carbon and nitrogen in carbonate-bearing sediments with a Yanaco MT-5 CHN analyzer. Limnol Oceanogr 40(5):1001-1005

Yonge CM (1932) Notes on feeding and digestion in Pterocera and Vermetus, with a discussion on the occurrence of the crystalline style in the gastropoda. Sci Rep Gt Barrier Reef Exped 1:259-281

Submitted: November 22, 1999; Accepted: March 24, 2000

Proofs received from author(s): September 13, 2000 